\author{
D. O. Thomas-Rueddel \\ V. Vlasakov \\ K. Reinhart \\ R. Jaeschke \\ H. Rueddel \\ R. Hutagalung \\ A. Stacke \\ C. S. Hartog
}

\section{Safety of gelatin for volume resuscitation-a systematic review and meta-analysis}

Received: 13 December 2011

Accepted: 13 March 2012

Published online: 18 April 2012

(C) Copyright jointly held by Springer and ESICM 2012

Congress abstracts were presented at the 5 th International Congress "Sepsis update" of the German Sepsis Society, Weimar, Germany, 7-10 September 2011, and the 24th ESICM Annual Congress, Berlin, Gerrmany, 1-5 October 2011.

D.O. Thomas-Rueddel and V. Vlasakov contributed equally to this work.

Electronic supplementary material The online version of this article (doi:10.1007/s00134-012-2560-x) contains supplementary material, which is available to authorized users.

D. O. Thomas-Rueddel · V. Vlasakov ·

K. Reinhart (®) · H. Rueddel .

R. Hutagalung - A. Stacke - C. S. Hartog

Department of Anesthesiology

and Intensive Care Medicine,

Jena University Hospital, Friedrich Schiller

University Jena, Erlanger Allee 101,

07747 Jena, Germany

e-mail: konrad.reinhart@med.uni-jena.de

Tel.: +49-3641-9323101

Fax: +49-3641-9323102
D. O. Thomas-Rueddel •

H. Rueddel - C. S. Hartog

Center for Sepsis Control and Care (CSCC

Jena), Integrated Research and Treatment

Center, Friedrich Schiller University Jena,

Erlanger Allee 101, 07747 Jena, Germany

R. Jaeschke

Department of Medicine and Department of Clinical Epidemiology and Biostatistics,

McMaster University, Hamilton, ON, Canada

Abstract Purpose: Gelatin is frequently used as a volume expander in critical care. Our goal was to investigate its safety.

Methods: Systematic review of randomized controlled trials (RCT) in patients receiving gelatin for resuscitation in comparison to albumin or crystalloids. Results: We identified 40 RCTs published between 1976 and 2010 with 3,275 patients. Median sample size in the gelatin groups was 15 patients (range 10-249). Median gelatin dose was $17 \mathrm{ml} / \mathrm{kg}$ (range $6-57 \mathrm{ml} / \mathrm{kg})$. In $32 \mathrm{RCTs}(n=1,946 /$ $3,275,59 \%$ of all patients), the study period was $\leq 24.0 \mathrm{~h}$. Twenty-nine

RCTs $(n=\overline{2}, 001)$ investigated elective surgical patients, mostly undergoing cardiac surgery (18 RCTs, $n=819)$. Three RCTs $(n=723)$ investigated critically ill adults. Two RCTs $(n=59)$ were performed in emergency room patients, and six RCTs $(n=492)$ were performed in neonates or children. No study was adequately powered to investigate the frequency of patient-important outcomes. Risks were not statistically significantly different for mortality (RR 1.12, $95 \%$ confidence interval, 0.87-1.44) and exposure to allogeneic transfusion (RR 1.28, 0.89-1.83). On account of only few included studies and the small number of patients, subgroup analyses (high vs. low dose, $>24 \mathrm{~h}$ vs. shorter periods, and critically ill patients vs. others) were uninformative. Only three RCTs reported the occurrence of acute renal failure. Conclusion: Despite over 60 years of clinical practice, the safety and efficacy of gelatin cannot be reliably assessed in at least some settings in which it is currently used. We suggest the need to investigate and establish such safety.

Keywords Plasma expander . Acute renal failure - Coagulopathy . Colloids · Crystalloids 


\section{Introduction}

Gelatin, a degradation product of collagen [1], is a plasma expander used in patients in emergency departments, intensive care units, and operating and recovery rooms. Being one of the first synthetic colloids used for fluid resuscitation in humans [2], it came into more widespread use when different modifications of the gelatin molecules became available (oxypolygelatin [3], succinylated or modified fluid gelatin [4], and urea-linked gelatin [5]). These products entered the market long before current regulatory rules requiring proof of efficacy and safety of drugs came into existence [6].

Generally, gelatin solutions are considered to have no dosage-related side effects, specifically not impairing surgical hemostasis $[7,8]$, and being less harmful to the kidneys than other non-protein colloids $[9,10]$.

It was therefore surprising that retrospective analyses in observational studies found the use of gelatin to be associated with increased renal impairment and the need for transfusion products in patients with severe sepsis [11] and cardiac surgery [12]. Considering that the use of nonprotein colloids is not associated with improved clinical outcomes $[13,14]$, potentially harmful effects of gelatins should be carefully explored.

Cumulative effects of gelatin on mortality were previously assessed by two Cochrane groups as part of larger meta-analyses that included studies until 2007 or 2008, respectively. Perel et al. [13] compared gelatin to crystalloid fluids in 506 critically ill adult patients, whereas Bunn et al. [15] compared gelatin with albumin or PPF in 636 patients thought to need volume replacement. No review found a significant effect on mortality. However, effects on renal function or blood product use were not systematically explored. In view of the emerging safety concerns, we considered that a systematic overview of the current clinical evidence on the safety of gelatin would be timely.

\section{Methods}

Eligibility criteria

\section{Inclusion criteria}

Inclusion criteria were: (1) prospective, randomized controlled trials, (2) hospital or pre-hospital setting, (3) patients with acute hypovolemia with need for fluid resuscitation, (4) study fluid was administered for resuscitation, (5) at least one intervention group received gelatin solution, and (6) at least one intervention group received another resuscitation fluid.

\section{Exclusion criteria}

Exclusion criteria were: (1) only volunteers or blood donors were recruited, (2) administration of fluid was solely for the purpose of volume preloading before anesthesia including volume loading for neural block, acute normovolemic or hypervolemic hemodilution without subsequent intra- or postoperative use, (3) retracted studies [16], (4) unsuitable control fluids, i.e., other synthetic colloids (as those may have similar risk profile), and (5) study results published in a language other than English, German, French, or Italian.

\section{Search strategy}

Three electronic databases were searched: Ovid Medline (1948-May 2011), EMBASE (1947-May 2011), and the Cochrane Central Register of Controlled Trials (CENTRAL) (through May 2011). In addition, reference lists from studies that met the inclusion criteria and from published systematic reviews were hand searched. Authors were contacted for further clarification if necessary.

The search terms used in MEDLINE or EMBASE are provided in the Electronic Supplement. Cochrane CENTRAL was searched using MeSH descriptor Polygeline (exploded).

Study selection, validity appraisal, and data extraction

Two reviewers independently screened the results of the search. Full-text manuscripts of potentially eligible articles were obtained and assessed independently against inclusion and exclusion criteria. Two out of five reviewers read the full-text reports and independently extracted the data into a datasheet. Differences were then compared and resolved by agreement or referral to a third reviewer. If results of one study were included in different publications, all extracted data were collated under one publication, and the others were removed from the datasheet.

Study validity was assessed by a tool developed by the Cochrane Collaboration's tool for assessing risk of bias based on "low-high-uncertain" responses to the following seven domains: randomization, allocation concealment, blinding of participants, blinding of outcome assessment, incomplete outcome data, selective reporting, and other sources of bias [17].

Extracted data included: type and volume of gelatin, types and volumes of control fluids, fluid regimen, observation period, clinical condition, patient numbers, potential conflict of interest (COI) and type of funding, 
and reported outcomes. Outcomes of interest were defined as all-cause mortality at a time reported by the investigators, number of patients exposed to allogeneic blood products, acute kidney injury (AKI) by RIFLE criteria [18] or new need for renal replacement therapy (RRT), anaphylaxis, or itching. These outcomes were assessed in studies where gelatin was compared to suitable control fluids (albumin, plasma protein, or crystalloid); synthetic colloids such as hydroxyethyl starch, dextran, or other gelatins were defined as unsuitable control fluids because their comparative safety was not in question for this systematic review. Where possible, subgroup analyses were performed for different patient populations (i.e., critically ill, trauma, surgical patients), and subgroups with higher risk for gelatin effects were analyzed [highdose gelatin $(\geq 30 \mathrm{ml} / \mathrm{kg}$ ), study periods $>24 \mathrm{~h}$ ].

Data analysis

The primary analysis of the data was descriptive, determining the proportion of studies meeting each of the criteria. Data were analyzed using SPSS 17.0 for Windows (SPSS Inc, Chicago, IL). Summarized fluid volumes were calculated as median values from all reported mean or median fluid volumes or from median/mean values for cumulative dose and body weight, if available.
For studies with more than one suitable control group, all control comparisons were pooled for the overall metaanalysis.

The relative risk of death and the relative risk of allogeneic blood product transfusion were calculated using a random-effects model (RevMan 5.1, Cochrane Collaboration). We specified subgroup analyses by study duration ( $>24 \mathrm{~h}$ vs. shorter periods), total gelatin dose ( $\geq 30 \mathrm{ml} / \mathrm{kg}$ versus less), and study population (critically ill patients vs. others). The statistical program used excludes studies with no events from the pooled estimate of relative risk.

\section{Results}

Descriptives

The structured search yielded 1,288 reports, of which 210 were read in full. The final sample contained 40 RCTs (full list is provided in Electronic Supplement). Studies were published between 1976 and 2010. The study flow graph is shown in Fig. 1.

Risk of bias is shown in Fig. 2. Three studies had a a low risk of bias in all domains [19-21], and five studies had a low risk in all domains except blinding [22-26].

Fig. 1 Study flow

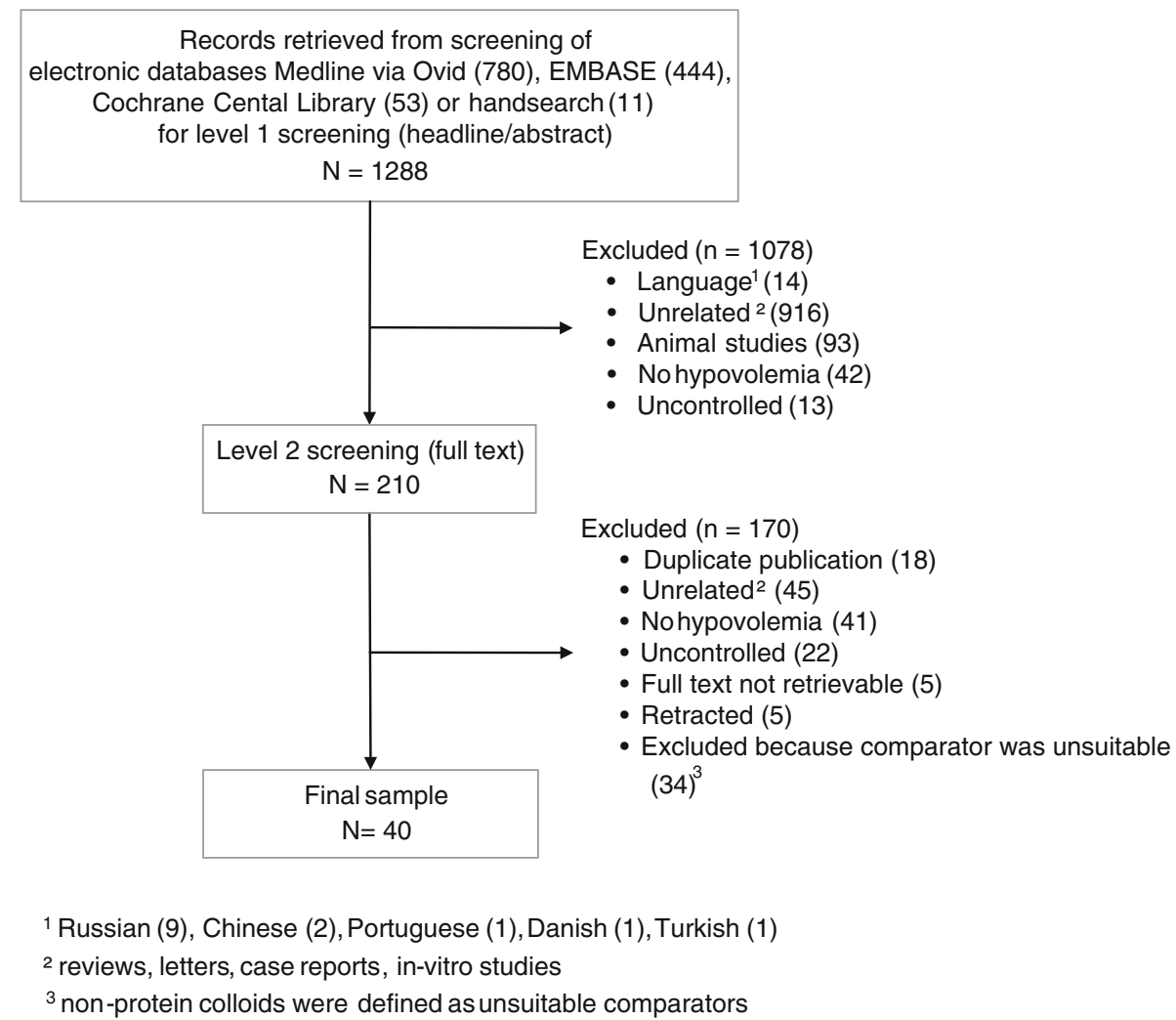


Fig. 2 Risk of bias in included studies

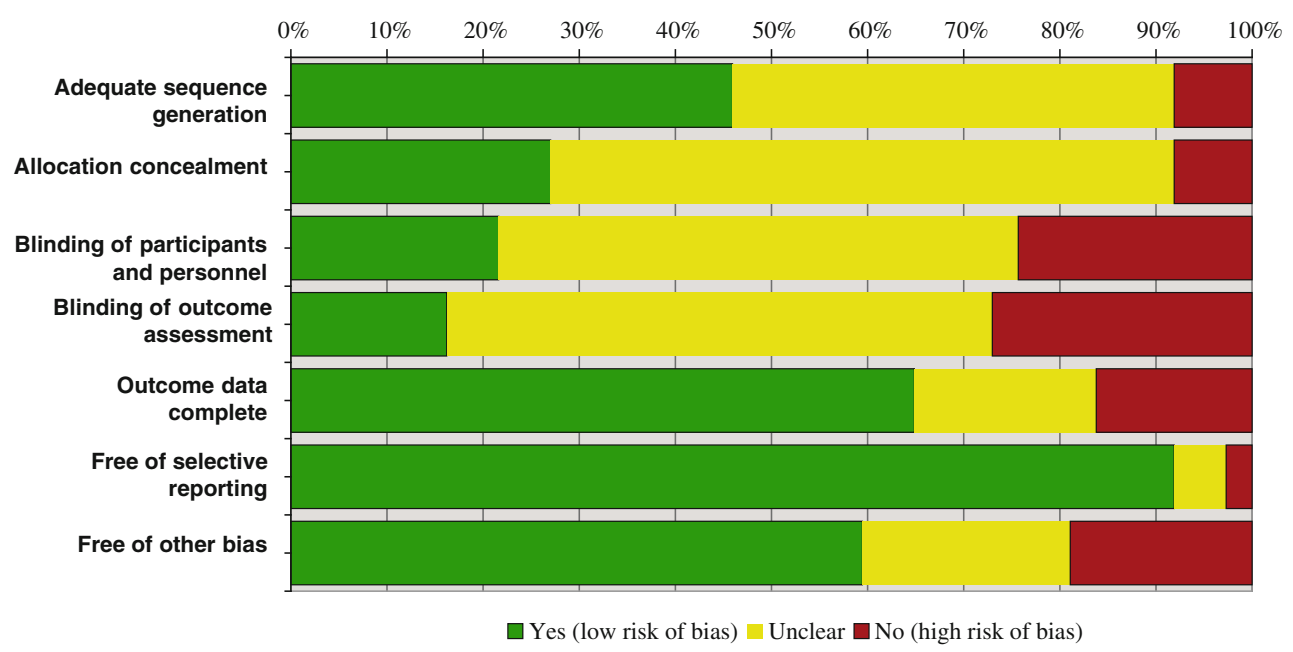

Characteristics of all included studies are shown in Table 1 . The total number of 3,275 patients was included in 40 studies, and 1,265 patients overall received gelatin. Median sample size in the gelatin groups was 15 patients (range 10-249). Two trials [27, 28] were multi-centered. In 32 RCTs ( $80 \%$ of RCTs, $n=1,946$ patients, $59 \%$ of all 3,275 patients), the study period was $\leq 24 \mathrm{~h}$. The total gelatin dose was $17 \mathrm{ml} / \mathrm{kg}$ (median, range 6-57). Twentynine RCTs (73\% of RCTs, 2,001/3,275, $61 \%$ of all patients) investigated elective surgical patients, mostly undergoing cardiac surgery (18 RCTs, 819 patients). Three RCTs (723 patients) investigated critically ill adults. Two RCTs (59 patients) were in emergency department patients, and six RCTs (492 patients) were in children (Table 1).

\section{Outcomes}

\section{Mortality}

Mortality rates were provided in 15 RCTs with 1,766 patients. Seven RCTs were in critically ill patients, and 8 RCTs were in trauma, emergency, or elective surgery. Overall mortality was similar in gelatin or control groups (RR 1.12, $95 \%$ confidence interval CI, 0.87-1.44) (Fig. 3a).

\section{Exposure to allogeneic blood products}

Eight RCTs with 712 patients reported the number of patients with transfusion of allogeneic blood products. Overall RR for exposure to allogeneic blood products was 1.28 (CI 0.89-1.83) (Fig. 3b).

\section{$A K I$ and need for RRT}

Only three RCTs ( $n=172$ patients) reported the occurrence of AKI, ARF, or new need for RRT [25, 29, 30]. In two of these studies, gelatin was used in high dosage; one RCT was in critically ill adults and one in critically ill children. There was no difference in the risk of AKI between groups with a wide confidence interval around the RR estimate (Fig. 3c).

\section{Subgroups}

Higher doses of gelatin were used in four RCTs that reported deaths; no difference was seen between fluid groups. Exposure to allogeneic transfusions could be assessed in one RCT with high-dose gelatin; the RR was 7.62 (95\% CI $1.05,55.55$, only 9 transfusion events) [31] (Table 2).

Study periods longer than $24 \mathrm{~h}$ were found in six RCTs that reported mortality, and in two RCTs that reported exposure to allogeneic transfusions. No difference was seen between groups (Table 2).

\section{Other outcomes}

Ten RCTs reported anaphylactoid reactions, but events occurred only in two RCTs (1/44 and 5/56 in the gelatin group, and 0/44 and 0/111 in the control groups) [21, 32]. No RCTs reported itching.

\section{Discussion}

This systematic review included all controlled studies that randomized adult and pediatric patients with acute hypovolemia due to surgery, trauma, severe infection, or critical illness to receive either gelatin or suitable albumin or crystalloid control fluids for resuscitation. We did not consider synthetic colloids as suitable control fluids because they have a similar risk profile 
Table 1 Characteristics of included studies

\begin{tabular}{|c|c|c|c|c|c|c|}
\hline First author & Year & Patients & Population & Type of gelatin & $\begin{array}{l}\text { Crystalloid } \\
\text { or albumin } \\
\text { comparator }\end{array}$ & $\begin{array}{l}\text { Additional } \\
\text { comparator } \\
\text { fluids and comments }\end{array}$ \\
\hline Akech & 2006 & 88 & Children with severe malaria & MFG $4 \%$ & Albumin $4.5 \%$ & \\
\hline Dung & 1999 & 50 & $\begin{array}{l}\text { Children with Dengue shock } \\
\text { syndrome }\end{array}$ & MFG $3 \%$ & NS, RL & $6 \%$ dextran 70 \\
\hline Haas & 2007 & 42 & $\begin{array}{l}\text { Small infants undergoing elective } \\
\text { surgery }\end{array}$ & MFG $4 \%$ & Albumin $5 \%$ & $6 \%$ HES $130 / 0.4$ \\
\hline Ngo & 2001 & 222 & $\begin{array}{l}\text { Children with Dengue shock } \\
\text { syndrome }\end{array}$ & MFG $3 \%$ & RL, NS & $6 \%$ dextran 70 \\
\hline Stoddart & 1996 & 30 & Neonates with elective surgery & Polygeline $3.5 \%$ & Albumin $4.5 \%$ & \\
\hline Upadhyay & 2005 & 60 & Children with septic shock & Polygeline $3.5 \%$ & & \\
\hline Gondos & 2010 & 200 & Critically ill adults & MFG $4 \%$ & RL, Albumin $5 \%$ & $6 \%$ HES $130 / 0.4$ \\
\hline Stockwell & 1992 & 475 & Critically ill adults & Polygeline $3.5 \%$ & Albumin $4.5 \%$ & $\begin{array}{l}\text { Patients received } \\
\text { additional albumin }\end{array}$ \\
\hline $\begin{array}{l}\text { van der } \\
\text { Heijden }\end{array}$ & 2009 & 48 & Critically ill adults & MFG $4 \%$ & NS, Albumin $5 \%$ & $6 \%$ HES 200/0.5 \\
\hline Boldt & 1986 & 55 & Adults with cardiac surgery & Polygeline $3.5 \%$ & Albumin $20 \%$ & $\begin{array}{l}3 \% \text { HES } 200 / 0.5 ; \\
\text { additional FFP and } \\
\text { albumin in both groups }\end{array}$ \\
\hline Boldt & 1992 & 60 & Adults with cardiac surgery & Gelatin $3.5 \%$ & $\begin{array}{l}\text { RL, Albumin } 20 \% \\
5 \%\end{array}$ & $\begin{array}{l}10 \% \text { HES } 200 / 0.5 \\
\text { additional albumin in } \\
\text { both groups }\end{array}$ \\
\hline Boldt & 1993 & 75 & Adults with cardiac surgery & Gelatin $3.5 \%$ & $\begin{array}{l}\text { Crystalloid, albumin } \\
5 \%\end{array}$ & $\begin{array}{l}6 \% \text { HES } 450 / 0.5,6 \% \\
\text { HES } 200 / 0.5 ; \text { additional } \\
\text { albumin in both groups }\end{array}$ \\
\hline Himpe & 1991 & 105 & Adults with cardiac surgery & $\begin{array}{c}\text { Polygeline } 3.5 \% \text {, } \\
\text { MFG } 3 \%\end{array}$ & Albumin $20 \%$ & \\
\hline Liskaser & 2000 & 21 & Adults with cardiac surgery & Polygeline $3.5 \%$ & NS & \\
\hline Schramko & 2010 & 45 & Adults with cardiac surgery & MFG $4 \%$ & $\mathrm{R}-\mathrm{Ac}$ & $6 \%$ HES 130/0.4 \\
\hline Scott & 1995 & 93 & Adults with cardiac surgery & Polygeline $3.5 \%$ & NS, albumin $4.6 \%$ & $\begin{array}{l}\text { All patients received } \\
\text { additional colloids }\end{array}$ \\
\hline Soares & 2009 & 40 & Adults with cardiac surgery & $\begin{array}{l}\text { MFG, percentage } \\
\text { unclear }\end{array}$ & NS & \\
\hline Tabuchi & 1995 & 60 & Adults with cardiac surgery & Oxypolygelatine & Albumin $20 \%$ & $10 \%$ HES $200 / 0.5$ \\
\hline Tigchelaar & 1998 & 33 & Adults with cardiac surgery & MFG $3 \%$ & Albumin $4 \%$ & \\
\hline Tollofsrud & 1995 & 40 & Adults with cardiac surgery & Polygeline $3.5 \%$ & R-Ac, albumin $4 \%$ & $6 \%$ dextran 70 \\
\hline Wahba & $1996 \mathrm{a}$ & 20 & Adults with cardiac surgery & Polygeline $3.5 \%$ & Albumin $5 \%$ & \\
\hline Wahba & $1996 b$ & 20 & Adults with cardiac surgery & Polygeline $3.5 \%$ & Ringers & \\
\hline DuGres & 1989 & 30 & Adults post cardiac surgery & Polygeline $3.5 \%$ & Albumin $4 \%$ & \\
\hline Kuitunen & 2007 & 45 & Adults post cardiac surgery & MFG $4 \%$ & Albumin $4 \%$ & $6 \%$ HES 200/0.5 \\
\hline Karanko & 1987 & 37 & Adults post cardiac surgery & $\begin{array}{l}\text { Oxypolygelatine } \\
5.5 \%\end{array}$ & $\begin{array}{r}\text { Plasma protein } \\
\text { solution } 4 \%\end{array}$ & $\begin{array}{l}6 \% \text { dextran } 70 ; \text { patients } \\
\text { received unspecified } \\
\text { colloids prior to study }\end{array}$ \\
\hline Verheij & 2006 & 67 & $\begin{array}{l}\text { Adults post cardio-thoracic } \\
\text { surgery }\end{array}$ & MFG $4 \%$ & NS, albumin $5 \%$ & $\begin{array}{l}6 \% \text { HES } 200 / 0.5 ; \text { all } \\
\text { patients received } \\
\text { gelatin for cardiac } \\
\text { prime }\end{array}$ \\
\hline Evans & 2003 & 55 & Adults with orthopedic surgery & $\begin{array}{l}\text { Polygeline } 3.5 \% \text {, } \\
\text { MFG } 4 \%\end{array}$ & NS, albumin $4.5 \%$ & \\
\hline Fries & 2004 & 60 & Adults with orthopedic surgery & MFG $4 \%$ & RL & $6 \%$ HES 200/0.5 \\
\hline Karoutsos & 1999 & 42 & Adults with orthopedic surgery & MFG $3.5 \%$ & Albumin $5 \%$ & $6 \%$ HES 200/0.6 \\
\hline Mittermayr & 2007 & 61 & Adults with orthopedic surgery & MFG $4 \%$ & RL & $6 \%$ HES 130/0.4 \\
\hline Parker & 2004 & 396 & Adults with orthopedic surgery & MFG $4 \%$ & NS & \\
\hline Evans & 1996 & 25 & Adult trauma patients & Polygeline $3.5 \%$ & RL & \\
\hline $\mathrm{Wu}$ & 2001 & 34 & $\begin{array}{l}\text { Adults with hypovolemic or } \\
\text { neurogenic shock }\end{array}$ & MFG $4 \%$ & RL & \\
\hline Lamke & 1976 & 83 & Adults with elective surgery & Polygeline $3.5 \%$ & NS, Albumin $5 \%$ & $\begin{array}{l}6 \% \text { Dextran 70, } 6 \% \text { HES } \\
\text { (Volex) }\end{array}$ \\
\hline Korttila & 1983 & 132 & Adults with elective surgery & MFG $4 \%$ & $\begin{array}{l}\text { Balanced glucose/ } \\
\text { salt solution }\end{array}$ & $\begin{array}{l}6 \% \text { dextran, } 6 \% \text { HES } \\
120,6 \% \text { HES } 70\end{array}$ \\
\hline Lorenz & 1994 & 231 & Adults with elective surgery & Polygeline $3.5 \%$ & RL & \\
\hline van Wyk & 1998 & 20 & Adults with elective surgery & Polygeline $3.5 \%$ & RL & \\
\hline
\end{tabular}


Table 1 continued

\begin{tabular}{|c|c|c|c|c|c|c|}
\hline First author & Year & Patients & Population & Type of gelatin & $\begin{array}{l}\text { Crystalloid } \\
\text { or albumin } \\
\text { comparator }\end{array}$ & $\begin{array}{l}\text { Additional } \\
\text { comparator } \\
\text { fluids and comments }\end{array}$ \\
\hline Volta & 2007 & 36 & $\begin{array}{l}\text { Adults with major abdominal } \\
\text { surgery }\end{array}$ & Polygeline $3.4 \%$ & RL & $6 \%$ HES 130/0.4 \\
\hline Vedrinne & 1991 & 30 & $\begin{array}{l}\text { Adults undergoing surgery with } \\
\text { neural block }\end{array}$ & MFG $3 \%$ & RL & $3.5 \%$ Dextran 40 \\
\hline Jin & 2010 & 36 & $\begin{array}{l}\text { Adults with major abdominal } \\
\text { surgery }\end{array}$ & MFG $4 \%$ & RL & $6 \%$ HES 130/0.4 \\
\hline
\end{tabular}

$M F G$ modified or fluid gelatin, $N S$ normal saline, $R L$ Ringer's lactate, $R$-Ac Ringer's acetate, $H E S$ hydroxyethyl starch

References for Table 1 are given in the Electronic Supplementary Material

and may all be associated with coagulopathy, renal dysfunction, and anaphylaxis [33, 34], whereas albumin and crystalloids are not associated with these side effects. Main outcomes were mortality, need for transfusion of allogeneic blood products, and renal failure reported as AKI according to RIFLE criteria or new need for RRT.

There was no difference in the overall risks of death and of patient exposure to allogeneic transfusions. However, all point estimates were on the one side of the potential range, and their confidence ranges were wide. Considering blood product use, the effect estimate by fixed effect model achieved significance (RR 1.36 [1.02, $1.81]$ ), while the more conservative random effect model did not (RR 1.28 [0.89, 1.83]). RR for exposure to transfusion was increased in the subgroup of high-dose gelatin use (RR $7.62[1.05,55.55]$ ), but here only one RCT was included [31], and the result is very imprecise. Almost all studies had considerable risk of bias and small sample sizes. The study period was $24 \mathrm{~h}$ or less in threequarters of studies, and two-thirds investigated elective surgical patients, mostly from cardiac surgery, making inferences regarding the use of those fluids in critically ill patients more difficult.

Except for three studies [25, 29, 30], no RCT assessed renal failure in terms of AKI or RRT in comparison to a suitable control fluid. There are only few reports of renal nephroses associated with gelatin $[35,36]$ and one case report of acute renal failure after vascular surgery [37]. Recently, retrospective analyses found that AKI occurred more frequently in patients with sepsis as well as cardiac surgical patients who received gelatin compared to patients who had received only crystalloids $[11,12]$. In each case we consider the evidence regarding influence of gelatins on renal outcome in critically ill patients as having low quality. Two previous fluid trials with critically ill patients found that the older $6 \%$ starch solution had more deleterious effects on kidney function than a $3 \%$ gelatin solution $[9,10]$. Small trials that compared thirdgeneration starches with $4 \%$ gelatin solution in cardiac surgical patients found no difference in renal function $[38,39]$, whereas a retrospective sequential analysis of 346 patients with severe sepsis found that AKI occurred in $70 \%$ of patients with HES 130/0.4 (adjusted $p=0.002)$ and in $68 \%$ of patients with $4 \%$ gelatin (adjusted $p=0.025$ ) compared to $47 \%$ of patients receiving only crystalloids [11].

The strength of this review is the comprehensive approach that identified RCTs published over the last 35 years, the systematic focus on potentially harmful effects, and the selection of studies with suitable control fluids. A limitation of its conclusion is the overall poor quality of the evidence coming from analysis of the included studies. This results from the design limitations of numerous studies, bringing their validity into question, imprecision stemming from the small numbers of events, indirectness about to the clinically important use of those drugs in critically ill populations, short observation periods, and relatively low doses used. In our view, the available data do not allow definitive inferences about the safety of gelatins in the populations of interest, especially when gelatins are used in larger doses over longer periods of time.

\section{Conclusion}

Gelatins were introduced into clinical practice before legislation in the aftermath of the thalidomide tragedy made clinical proof of safety mandatory [6]. Despite over 60 years of clinical experience with its use, the safety of gelatin in all settings in which it is used cannot be reliably assessed and confirmed. We suggest the need to investigate and establish such safety. 


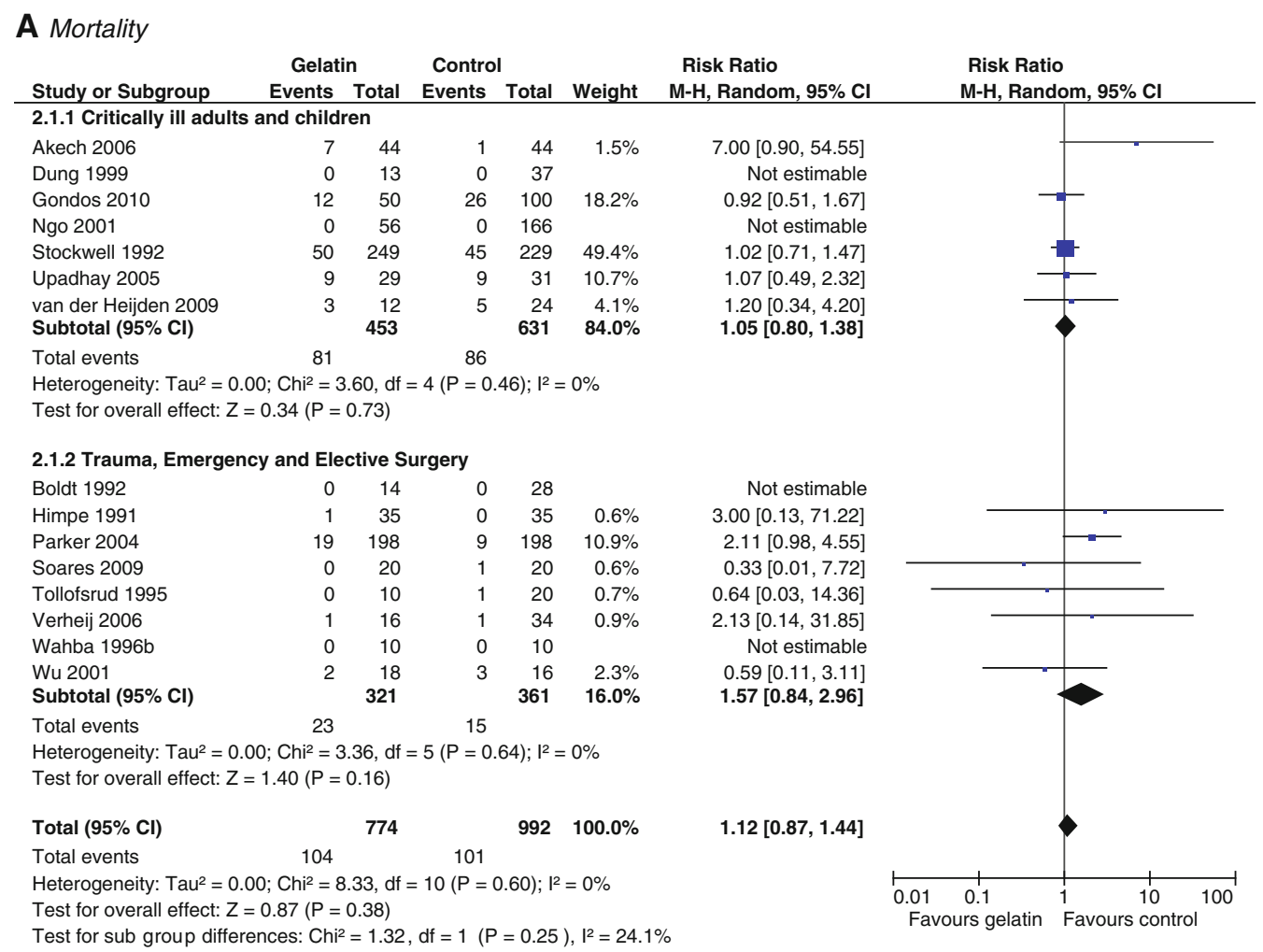

\section{B Exposure to allogeneic transfusions}

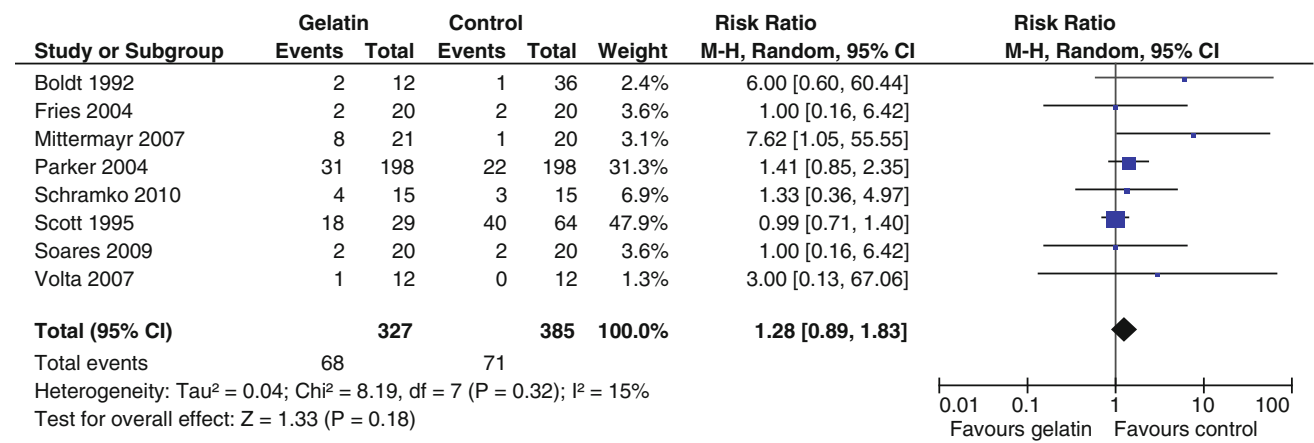

C Acute kidney injury ${ }^{1}$

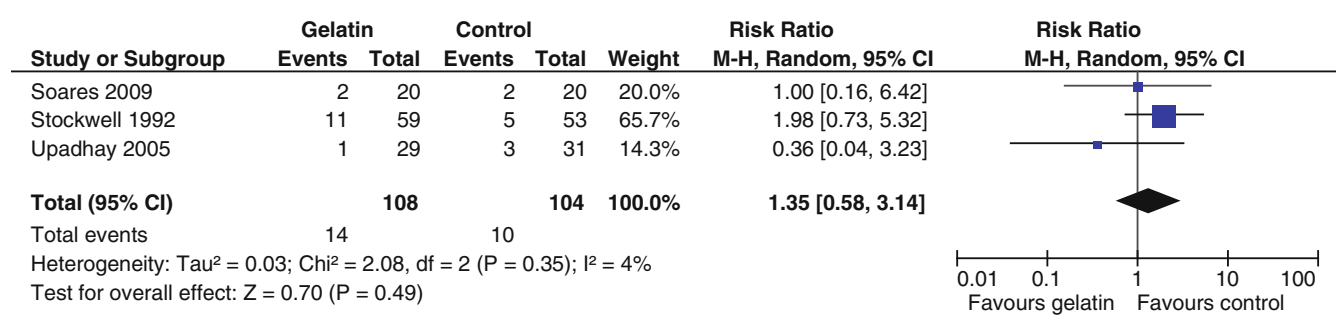

${ }^{1} \mathrm{AKI}$ defined as serum urea $>30 \mathrm{mmol} / \mathrm{L}$, or requirement for renal replacement therapy [29] or

abnormal serum creatinine and urinary spot sodium of $>40 \mathrm{mmol} / \mathrm{L}$, or an increase in serum creatinine by $2.0 \mathrm{mg} / \mathrm{dL}$ (176 $\mu \mathrm{mol} / \mathrm{L})$ [25] or elevation of creatinine above $1.5 \mathrm{mg} / \mathrm{dL}$ [30].

Fig. 3 Forest plots of pooled estimates 
Table 2 Subgroup outcomes

\begin{tabular}{|c|c|c|c|c|c|c|}
\hline \multirow[t]{2}{*}{ Subgroup } & \multirow[t]{2}{*}{ Outcome } & \multirow[t]{2}{*}{ Studies } & \multirow[t]{2}{*}{ Patients } & \multicolumn{2}{|c|}{$\begin{array}{l}\text { No. of events/ } \\
\text { no. of patients }\end{array}$} & \multirow[t]{2}{*}{ Effect estimate $^{a}$} \\
\hline & & & & Gelatin & Control & \\
\hline \multirow[t]{2}{*}{ High dose ${ }^{b}$} & Mortality & 4 & 623 & $66 / 322$ & $55 / 301$ & $1.19(0.66,2.13)$ \\
\hline & Exposure to allogeneic transfusions & 1 & 41 & $8 / 21$ & $1 / 20$ & $7.62(1.05,55.55)$ \\
\hline \multirow[t]{2}{*}{$>24 \mathrm{~h}$} & Mortality & 6 & 1,213 & $69 / 558$ & $55 / 655$ & $1.27(0.72,2.22)$ \\
\hline & Exposure to allogeneic transfusions & 2 & 420 & $32 / 210$ & $22 / 210$ & $1.44(0.87,2.38)$ \\
\hline
\end{tabular}

a Statistical method: risk ratio (M-H, random, $95 \% \mathrm{CI}) ;<1$ favors gelatin, $>1$ favors control

b Gelatin dose $\geq 30 \mathrm{ml} / \mathrm{kg}$

Acknowledgments Support was provided solely from institutional and/or departmental sources.

Conflicts of interest None.

\section{References}

1. Saddler JM, Horsey PJ (1987) The new generation gelatins. A review of their history, manufacture and properties. Anaesthesia 42:998-1004

2. Hogan JJ (1915) The intravenous use of colloidal (gelatin) solutions in shock. JAMA 64:721-726

3. Campbell DH, Koepfli JB, Pauling L, Abrahamsen N, Dandliker W, Feigen GA, Lanni F, Le RA (1951) The preparation and properties of a modified gelatin (Oxypolygelatin) as an oncotic substitute for serum albumin. Tex Rep Biol Med 9:235-280

4. Parkins WM, Perlmutt JH, Vars HM (1953) Dextran, oxypolygelatin and modified fluid gelatin as replacement fluids in experimental hemorrhage. Am J Physiol 173:403-410

5. Schmidt-Thome J, Mager A, Schoene HH (1962) On the chemistry of a new plasma expander. Arzneimittelforschung 12:378-380

6. Ziporyn T (1985) The Food and Drug Administration: how those regulations came to be. JAMA 254:2037-2039, 2043-2036

7. Lundsgaard-Hansen $P$, Tschirren B (1980) Clinical experience with 120,000 units of modified fluid gelatin. Dev Biol Stand 48:251-256

8. de Jonge E, Levi M (2001) Effects of different plasma substitutes on blood coagulation: a comparative review. Crit Care Med 29:1261-1267

9. Cittanova ML, Leblanc I, Legendre C, Mouquet C, Riou B, Coriat P (1996) Effect of hydroxyethylstarch in braindead kidney donors on renal function in kidney-transplant recipients. Lancet 348:1620-1622
10. Schortgen F, Lacherade JC, Bruneel F, Cattaneo I, Hemery F, Lemaire F, Brochard L (2001) Effects of hydroxyethylstarch and gelatin on renal function in severe sepsis: a multicentre randomised study. Lancet 357:911-916

11. Bayer O, Reinhart K, Sakr Y, Kabisch B, Kohl M, Riedemann NC, Bauer M, Settmacher U, Hekmat K, Hartog CS (2011) Renal effects of synthetic colloids and crystalloids in patients with severe sepsis: a prospective sequential comparison. Crit Care Med 39:1335-1342

12. Bayer O, Kohl M, Kabisch B, Sakr Y, Schelenz C, Bauer M, Riedemann N, Badreldin A, Doenst T, Hartog C, Reinhart K (2011) Effects of synthetic colloids on renal function in cardiac surgical patients. Intensive Care Med 37:S202

13. Perel P, Roberts I (2011) Colloids versus crystalloids for fluid resuscitation in critically ill patients. Cochrane database of systematic reviews (Online) 3:CD000567

14. Brunkhorst FM, Engel C, Bloos F, Meier-Hellmann A, Ragaller M, Weiler N, Moerer O, Gruendling M, Oppert M, Grond S, Olthoff D, Jaschinski U, John S, Rossaint R, Welte T, Schaefer M, Kern P, Kuhnt E, Kiehntopf M, Hartog C, Natanson C, Loeffler M, Reinhart K (2008) Intensive insulin therapy and pentastarch resuscitation in severe sepsis. New Eng J Med 358:125-139

15. Bunn F, Trivedi D, Ashraf S (2011) Colloid solutions for fluid resuscitation. Cochrane database of systematic reviews (Online) 3:CD001319
16. Editors in-Chief statement regarding published clinical trials conducted without IRB approval by Joachim Boldt,http://journals.lww.com/ ejanaesthesiology/Documents/ EIC\%20Joint\%20Statement\% 20on\%20Retractions\%2012Mar2011. pdf. Accessed 12 March 2011 DOI

17. Higgins JPT, Green S (eds) (2011) Cochrane Handbook for Systematic Reviews of Interventions Version 5.1.0. The Cochrane Collaboration. http://www.cochrane-handbook.org. Accessed March 2011

18. Mehta RL, Kellum JA, Shah SV, Molitoris BA, Ronco C, Warnock DG, Levin A (2007) Acute kidney injury network: report of an initiative to improve outcomes in acute kidney injury. Crit Care (London, England) 11:R31

19. Dung NM, Day NP, Tam DT, Loan HT, Chau HT, Minh LN, Diet TV, Bethell DB, Kneen R, Hien TT, White NJ, Farrar JJ (1999) Fluid replacement in dengue shock syndrome: a randomized, double-blind comparison of four intravenous-fluid regimens. Clin Infect Dis 29:787-794

20. Lorenz W, Duda D, Dick W, Sitter H, Doenicke A, Black A, Weber D, Menke H, Stinner B, Junginger T et al (1994) Incidence and clinical importance of perioperative histamine release: randomised study of volume loading and antihistamines after induction of anaesthesia. Trial Group Mainz/ Marburg. Lancet 343:933-940 
21. Ngo NT, Cao XT, Kneen R, Wills B, Nguyen VM, Nguyen TQ, Chu VT, Nguyen TT, Simpson JA, Solomon T, White NJ, Farrar J (2001) Acute management of dengue shock syndrome: a randomized double-blind comparison of 4 intravenous fluid regimens in the first hour. Clin Infect Dis 32:204-213

22. Evans PA, Heptinstall S, Crowhurst EC, Davies T, Glenn JR, Madira W, Davidson SJ, Burman JF, Hoskinson J, Stray CM (2003) Prospective doubleblind randomized study of the effects of four intravenous fluids on platelet function and hemostasis in elective hip surgery. J Thromb Haemost 1:2140-2148

23. Jin SL, Yu BW (2010) Effects of acute hypervolemic fluid infusion of hydroxyethyl starch and gelatin on hemostasis and possible mechanisms. Clin Appl Thromb Hemost 16:91-98

24. Schramko AA, Suojaranta-Ylinen RT, Kuitunen AH, Raivio PM, Kukkonen SI, Niemi TT (2010) Comparison of the effect of $6 \%$ hydroxyethyl starch and gelatine on cardiac and stroke volume index: a randomized, controlled trial after cardiac surgery. Perfusion 25:283-291

25. Upadhyay M, Singhi S, Murlidharan J, Kaur N, Majumdar S (2005) Randomized evaluation of fluid resuscitation with crystalloid (saline) and colloid (polymer from degraded gelatin in saline) in pediatric septic shock. Indian Pediatr 42:223-231

26. van der Heijden M, Verheij J, van Nieuw Amerongen GP, Groeneveld AB (2009) Crystalloid or colloid fluid loading and pulmonary permeability, edema, and injury in septic and nonseptic critically ill patients with hypovolemia. Crit Care Med 37:1275-1281
27. Gondos T, Marjanek Z, Ulakcsai Z, Szabo Z, Bogar L, Karolyi M, Gartner B, Kiss K, Havas A, Futo J (2010) Short-term effectiveness of different volume replacement therapies in postoperative hypovolaemic patients. Eur J Anaesthesiol 27:794-800

28. Korttila K, Lauritsalo K, Sarmo A, Gordin A, Sundberg S (1983)

Suitability of plasma expanders in patients receiving low-dose heparin for prevention of venous thrombosis after surgery. Acta Anaesthesiol Scand 27:104-107

29. Stockwell MA, Scott A, Day A, Riley B, Soni N (1992) Colloid solutions in the critically ill. A randomised comparison of albumin and polygeline 2. Serum albumin concentration and incidences of pulmonary oedema and acute renal failure. Anaesthesia 47:7-9

30. Soares RR, Ferber L, Lorentz MN, Soldati MT (2009) Intraoperative volume replacement: crystalloids versus colloids in surgical myocardial revascularization without cardiopulmonary bypass. Revista brasileira de anestesiologia 59:439-451

31. Mittermayr M, Streif W, Haas T, Fries D, Velik-Salchner C, Klingler A, Oswald E, Bach C, Schnapka-Koepf M, Innerhofer P (2007) Hemostatic changes after crystalloid or colloid fluid administration during major orthopedic surgery: the role of fibrinogen administration. Anesth Analg 105:905-917

32. Akech S, Gwer S, Idro R, Fegan G, Eziefula AC, Newton CR, Levin M, Maitland K (2006) Volume expansion with albumin compared to gelofusine in children with severe malaria: results of a controlled trial. PLoS Clin Trials $1: \mathrm{e} 21$
33. Barron ME, Wilkes MM, Navickis RJ (2004) A systematic review of the comparative safety of colloids. Arch Surg 139:552-563

34. Groeneveld AB, Navickis RJ, Wilkes MM (2011) Update on the comparative safety of colloids: a systematic review of clinical studies. Ann Surg 253:470-483

35. Skinses OK (1947) Gelatin nephrosis; renal tissue changes in man resulting from the intravenous administration of gelatin. Surg Gynecol Obstet 85:563-571

36. Kief H, Engelbart K, Arnold G, Baehr H (1968) Vacuolar reabsorption of native and digested gelatin (so-called osmotic nephrosis). Virchows Arch Abb B Zellpathol 1:240-250

37. Hussain SF, Drew PJ (1989) Acute renal failure after infusion of gelatins. BMJ 299:1137-1138

38. Godet G, Lehot JJ, Janvier G, Steib A, De Castro V, Coriat P (2008) Safety of HES 130/0.4 (Voluven(R)) in patients with preoperative renal dysfunction undergoing abdominal aortic surgery: a prospective, randomized, controlled, parallel-group multicentre trial. Eur J Anaesthesiol 25:986-994

39. Ooi JS, Ramzisham AR, Zamrin MD (2009) Is 6\% hydroxyethyl starch $130 / 0.4$ safe in coronary artery bypass graft surgery? Asian Cardiovasc Thorac Annals 17:368-372 